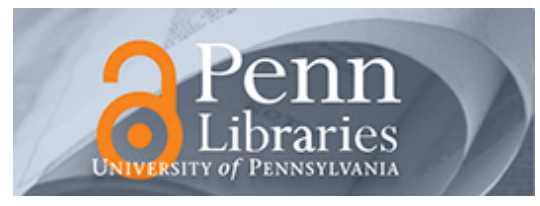

Studies in Visual Communication

Volume 1

Issue 1 Fall 1974

Article 4

1974

\title{
Symbolic Functions of "Drug Abuse": A Mass Communication Approach
}

George Gerbner

\section{Recommended Citation}

Gerbner, G. (1974). Symbolic Functions of "Drug Abuse": A Mass Communication Approach. 1 (1), 27-34. Retrieved from https://repository.upenn.edu/svc/vol1/iss1/4

This paper is posted at ScholarlyCommons. https://repository.upenn.edu/svc/vol1/iss1/4

For more information, please contact repository@pobox.upenn.edu. 
Symbolic Functions of "Drug Abuse": A Mass Communication Approach

This contents is available in Studies in Visual Communication: https://repository.upenn.edu/svc/vol1/iss 1/4 


\section{SYMBOLIC FUNCTIONS OF "DRUG ABUSE": A MASS COMMUNICATION APPROACH}

\section{GEORGE GERBNER}

Communication research is typically concerned with systems of messages and the patterns of thinking, action, and policy that such systems tend to cultivate. "Image" is one of the most versatile terms of such research. It stands both for a mental construct and the cultural artifact that sustains it. The transaction that we might call "imaging" (imagining without its connotation of "unreality") is to the brain what breathing is to the lungs. Both involve an exchange of energies with environmental systems common-and vital-to all humans.

The environmental system we call culture is entirely artifactual and largely symbolic. Its common imagesstructures of words, pictures, sounds, movements, and other forms of expression or representation-create for most members of a culture the basic common assumptions that define the contours of reality and the range of issues to agree or disagree about. The ability to select, order, and weight these according to some perspective is the substance of human identity and integrity. The ability to do that on a mass scale for large and heterogeneous publics is the essence of culture power.

Mass communication is the mass production of images and their discharge into the mainstream of the common symbolic environment (Gerbner 1972a). The ability to print the Book and distribute it to laymen was necessary to break up a rigidly land-based religious order. The ability to massproduce and disseminate a total symbolic link that binds far-flung communities together has loosened the hold of all traditional religions on mental life and has created a new religion out of the merger of technology and culture power. The critical culture nexus of modern governance is no longer church and state; it is mass media and state.

Study of the pictorial component is of course an integral part of the investigation of popular movies, comics, television, and other visual-verbal media products (Hansen and Parsons 1968:61-67). Such investigations provide fruitful opportunities for the discovery of definitional and assumptive patterns implicit in complex and dynamic message systems. The typical purpose of the investigation is to find the aggregate, repetitive, and cumulative patterns to which entire communities are exposed. These patterns are the sum total of all individual selections; they are not necessarily

George Gerbner is a researcher in mass communication and popular culture. He is currently conducting studies in television content and effects. He is Professor of Communications and Dean of the Annenberg School of Communications, University of Pennsylvania. similar to any single individual selective pattern of media use. They form the symbolic links of community and the bases for interaction among publics that never meet face-to-face. They are the foundations of policy formation, maintenance, and control in modern societies. For example, our studies of the confession magazine cover design revealed how the the image of the radiant "cover girl" in the lurid verbal context served the symbolic functions prescribed for the workingclass reader in a consumer society (Gerbner 1958a, 1958b). Cross-cultural studies of media portrayal of the formal educational institutions suggested the existence of different symbolic functions of the "teacher image" in different societies (Gerbner 1973). Our continuing analysis of violence in television drama shows how a differential pattern of victimization suffered by different sex, age, ethnic, and other groups demonstrates a structure of social power and cultivates assumptions and fears conducive to the acceptance of that structure (Gerbner 1972b).

In sum, the mass production of popular imagery changed the nature of the social process. No more can we speak of "sheer" ignorance or apathy. In the midst of a symbol-rich environment ignorance and apathy are manufactured products. No cultural definition of any aspect of the human condition survives unless its continued manufacturing serves some market and some purpose. What may be seen as irrationality, superstition, "neglect" of public institutions of education and welfare, the persistence of ghettoes of the "underprivileged" and the "underdeveloped," and periodic wars upon those who try to break out of them-all these and other "crises" of the physical, social, and symbolic environment are sustained by the greatest mobilization of information, wealth, and power in human history.

Drug addiction is one of these "problems." Its cultural definitions and those of the ways to combat it serve markets and purposes other than just therapeutic; they may even function to perpetuate the very "abuses" they are out to conquer.

Not so long ago, narcotics in the U.S. were a luxury for the idle rich to enjoy in relative obscurity. It was only after World War II that the ghettoes of America reached the level of becoming lucrative markets for a commodity that helps to enslave its customers.

When a certain type of practice crosses class lines it may become vulgar or illegal or otherwise usable for stigmatization and control. Obscenity is Saxon peasant idiom intruding into the speech of Norman nobles. Crime is the ruled trying to act like rulers.

Congress made the sentencing of federal narcotics offenders mandatory in 1951. The number of arrests doubled within ten years. The largest outbreaks continued to occur in low-income neighborhoods, even if suburbs and campuses were to get the most publicity. Stiffer penalties speeded the process. By the mid-sixties it took only four years to double the rate of arrests. Most of them were-and still are-made in the areas where most of all arrests are made: the "underprivileged" neighborhoods. In July 1972 it was reported that President Nixon ordered arrests doubled in one year:

During a meeting in his Oval Office, Mr. Nixon pointed to a chart showing 16,144 arrests in fiscal 1972-compared with the 1969 figure of 8,465 -and said, "I'd like to see this number doubled next year." 
"We very likely may do that," responded Myles Ambrose, special consultant to the President and director of the Office of Drug Abuse Law Enforcement [Philadelphia Inquirer 1972].

The same week, long-suppressed government reports revealed that narcotics investigators saw "no prospect" of halting smuggling into the U.S. Despite daily reports of "record" seizures less than one percent of the heroin flow was intercepted. "It's nonsense to me to keep reading these stories about how we're going to stop it from growing," said $\mathrm{Mr}$. Ambrose. "The fact of the matter is that we're not thinking so much about the addicts as the 10 million other people they might infect," he added (New York Times 1972).

The estimate of ten million may turn out to be modest. The history of drug traffic intermingles with that of global and-wherever it took hold-of domestic imperialism. Tough little wars were fought to open China to Western fortunes through control of the opium trade. Making the trade illegal did not stop it. On the contrary, it gave the police vast powers to use at their discretion.

Our own culture has also defined the problem in a way that helps sustain a multi-billion dollar international industry largely on money siphoned off from the poorest sector of society. We may be the first country to use advanced marketing techniques to make genuine opiates the "opium of the people." Huge profits from improved exploitive efficiency reward high-risk capital and its official protectors at home and abroad. Enough terror has been generated to enable private and public "security" agencies to greatly strengthen the total surveillance and repression machinery available to cope with any opposition. The underlying cultural scenario is no more likely to achieve its purported aims than was prohibition or the Cold War. But, as those symbolic crusades, it may be a powerful if costly instrument of social control.

The evidence available to me suggests a cultural pincermovement. Act I of the scenario comes from that section of our mass culture in which the rituals of society are spelled out in unmistakable forms, the comics. It is a Faustian ploy, displaying a world of winners and losers and a rite de passage into the winners' circle. Delicious power, sweet immortality, astounding insight, and the ability to right all wrongs-yours but for one bold deal of defiance and daring.

Act II starts in agony and ends in hell. You fell for the oldest trick in the cultural repertory and are now trapped by the forces you set out to conquer. Captivity provides another opportunity for basic training in the socio-sexual-political lesson that underlies the entire scenario. Its form is that of "drug abuse" literature, and our case in point will be a widely distributed booklet appropriately entitled "Teen-Age Booby Trap."

\section{THE SCENARIO: ACT I}

Of all the symbolic quests that test human frailty few are as persistent as the lure of potent potions of pleasure, power, and profit. Over the last hundred years or so, this venerable motif has been finessed by the peddlers of drugs and nostrums who have subsidized so much of our emergent mass culture, and then by virtually the entire myth-making apparatus of the new populist commercialism. The cult of instant private gratification made into an article of democratic faith suggests and supports drug use (or "abuse") as the ideal style of life for the dutiful consumer literally addicted to his purchasing habits.

The nearest to outright promises of magic transformation from scrawny youngsters to dashing musclemen and Amazons are the elixir and health-gadget ads in comic books and similar materials. The more subtle attractions of sophisticated advertising are not too different. The clearest expressions of the basic appeal come from those ideal types of mass-produced culture heroes described in Jules Feiffer's book, The Great Comic Book Heroes:

That strange bubbly world of test tubes and gobbledy-gook which had, in the past, done such great work in bringing the dead back to life in the form of monsters-why couldn't it also make men super. Thus Joe Higgins went into his laboratory and came out as the Shield; and John Sterling went into his laboratory and came out as Steel Sterling; and Steve Rogers went in the laboratory of kindly Professor Reinsten and came out as Captain America; and kindly Professor Horton went into his laboratory and came out with a synthetic man, named, illogically, the Human Torch [Feiffer 1965].

The creation of Captain America is prophetic. In the first issue of the comic, the scientist examines a youthful "98 pound weakling." "Observe this young man closely," he says. "Today he volunteered for army service and was refused because of his unfit condition! His chance to serve his country seemed gone!!'"

The next frame is a close-up of the scientist lifting up a giant hypodermic needle, and the caption: "Don't be afraid son ... you are about to become one of America's saviors!" Then the narration: "Calmly the young man allows himself to be innoculated with the strange seething liquid. Little does he realize that the serum coursing through his blood is rapidly building his body and brain tissues, until his stature and intelligence increase to an amazing degree!" (Feiffer 1965).

Frederick Leaman, a member of my graduate communications research seminar, conducted an informal study of the hidden message of comic books. He visited three large drugstores in different sections of Philadelphia and asked for their best-selling comics. From a list of 204 titles, he selected all stories that depicted different casts of characters in order to diversify the sample and avoid having the same heroes in most books. From this group of 26 stories and 87 characters, he constructed a composite image of the world of popular (mostly action-adventure type) comics.

The world he found is a world of conflict and contest. Its stories endlessly reiterate brutal lessons of transgression and $\sin$. Of all the main themes contained in every 10 stories, 8 depict the foul deeds of criminals, 7 show the magic of science, 6 demonstrate how the forces of righteousness smash criminals or evil scientists, 5 percent miraculous transformations through drugs, and 4 relate some hair-raising lesson about "power-hungry" politicians.

The fictional population is male 4 to 1 (the usual representation of the sexes in the mass media), and predominantly young, white, middle-majority. Of every ten characters, 7 commit some crime, the same number fall victim of violence, and 6 inflict violence. Killers represent 13 percent of the population and their fatal victims 7 percent.

Virtually all stories present problems of life and death. 
But the real name of the social-symbolic game is power. It takes super-power and super-consciousness to wrest the world about. In more than half (54\%) of the stories, the key to super-status is the consumption of some chemical substance that can affect a drastic transformation.

On the whole, one out of every 5 characters uses drugs to seek super-power, ultra-intelligence, or eternal life. Scientists, as a group, are heavy users; some of then become (or try to become) super-heroes. Scientists administer the drugs even more frequently. While 28 percent of all scientists take drugs, 36 percent administer drugs. By comparison, 21 percent of all super-heroes use but only 4 percent give drugs. Here we begin to see a role differentiation between those who can bestow and those who may use the gift of superhuman insight and power. Of all users, 33\% are super-heroes, 28\% are scientists, and the rest is divided among other characters. Of all those who administer drugs, $56 \%$ are scientists and $33 \%$ are super-heroes.

Positive, active, violent characters use drugs most. The heroes of the comic book world comprise $67 \%$ of all drug-takers. Only $17 \%$ of their antagonists, the villains of the comic book world, use drugs.

When it comes to administering drugs, heroes are less important (but still in the majority), while villains double their representation. In other words, $67 \%$ of all drug users but only $56 \%$ of drug givers are heroes, while only $17 \%$ of all drug users but $33 \%$ of drug givers are villains.

The role of the drug user is thus relatively untainted by villainy. Heroes use drugs in a good cause. The drug giver is more likely to be evil, and also more likely to be a scientist.

1

Weak

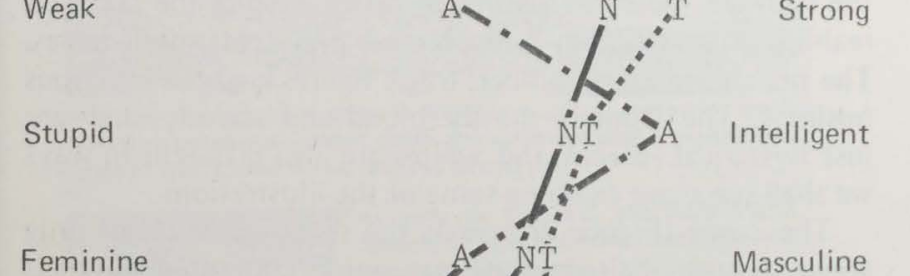

Elderly

Violent 2 3 4 5

Masculine

Youthful

Peaceful
Personality ratings provide a further clue to the dynamics of comic book power. Figure 1 shows the mean ratings of all 87 comic book characters on a series of personality traits. The broken line (marked "A" for "Administers drugs") shows the aggregate personality profile of all characters who dispense or inject the drugs in comparison with those who ingest them (dotted line) and those who neither give nor take them (solid line). The givers are relatively intelligent, but also relatively weak, effeminate, elderly, and peaceful. The takers as a group are (or become) more youthful and strong, and demonstrate through violence the power that flows from the potent potion, powder, or serum. The idependent intellect-sand in the gears of any consciousness industry-is neutralized by showing scientists or teachers as generally benign but impotent except to serve others. When they move outside the reach of responsible corporate service and control, and grab the powers they should bestow on others, they usually turn vicious or go mad. For example, in one comic book story of our sample the left-leaning professor of biochemistry, Derek Willden, neglects his attractive wife Sylvia to spend all his time in the laboratory working on a serum of eternal life. Scholarly but athletic professor Ross Cochran is named head of the department, but Derek doesn't care. "They're FOOLS!" . . he snorts, as he tells Sylvia his secret. "Oh really!" she retorts. "If you know the secret of the Universe, Derek, then why did Ross get promoted?" "This bourgeois materialistic thinking doesn't become you dear," he replies. "Soon... I shall be VINDICATED! Then ... just you and me, Sylvia! Together FOREVER!" But the elixir lacks one ingredient, a human gland, which Derek obtains by killing Ross who had by now become Sylvia's lover. The potion is now ready and he gulps it down-only to be arrested and sentenced to life imprisonment-forever!

Act $\mathbf{I}$ of the scenario is for everyone. Although comics spell it out most clearly, it is implicit in much of general news, advertisement, fiction, and drama. It is a ritual of power and of its promise through some individual act or intervention. The siren song warns against political solutions or the application of rationality as doomed to failure; power flows from the barrel of a gun or the hypodermic syringe.

\section{ACT II: "TEEN-AGE BOOBY TRAP"}

Act II is for those-the most disaffected, uprooted, powerless-who yield to the siren song that enthralls so many. "Try It, You'll Like It"-and now you're hooked. Our case in point is the widely used anti-drug booklet entitled "Teen-Age Booby Trap." It was produced in comic book style by Commercial Comics, Inc., of Washington, D.C., whose President, Malcolm W. Ater describes the effort in these words:

To be sure we produced the right kind of brochure-one which would be well received by the intended audience of children of junior and high school age-we sought the support and helpful guidance of experts in this field. I do not mean "self-styled" experts, but authorities whose counseling I could depend on for the best kind of evaluation. Major contributors in an editorial way were the Bureau of Narcotics and Dangerous Drugs, the Senate Judiciary Sub-committee on Juvenile Delinquency and the U.S. Department of Defense (Education) and we also had editorial approval of the American Pharmaceutical Association and the 
National Coordinating Council on Drug Abuse and Education. All the above named approved the copy before the magazines were first printed. The Bureau of Narcotics and Dangerous Drugs ordered a substantial quantity twice and the Department of Defense purchased 625,000 copies only after they had made an evaluation study of the cross-section of 18-25 year olds representative of their troops. The study was made by an independent organization outside the government and showed overwhelming acceptance of both the technique and the contents. I repeat, it was only because of this very high approval of the brochure that DOD made its purchase.

We have sold millions of copies and have filled orders for as low as 250 copies for school systems. The praise has not stopped coming in for this brochure [Ater 1972]

Let us examine this widely praised and well-tested work, approved by the highest authorities (except for a few "self-styled" experts). Again we shall probe for the lessons implicit in the world of people and events that the booklet reveals to its readers.

On the 32 pages and 57 frames of the booklet, about 142 persons are portrayed. More than half are males, and 13 percent are nonwhite. Active professional help or service comes mostly from males, nearly all white. Even nurses and hospital attendants are mostly male and all white. In fact, practically all work is performed by males; men are shown as scientists, teachers, doctors, farmers, firemen, and drivers. Women and nonwhites are portrayed only as drug addicts, or as listening to white males give lectures or orders.

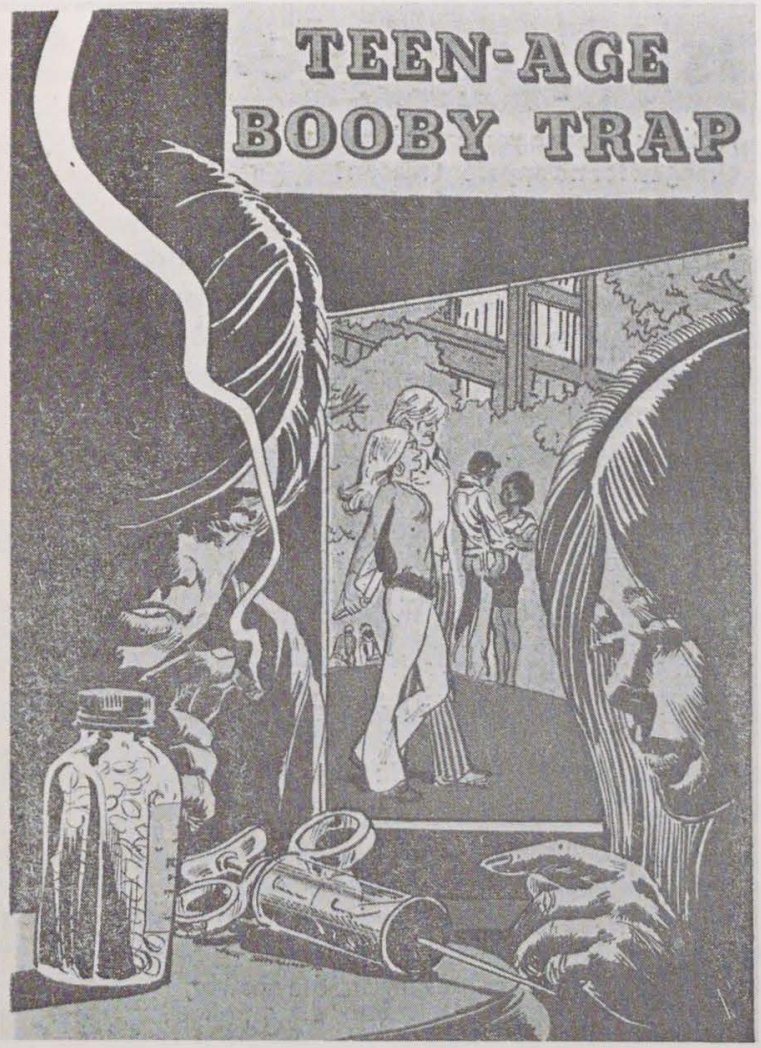

Figure 2

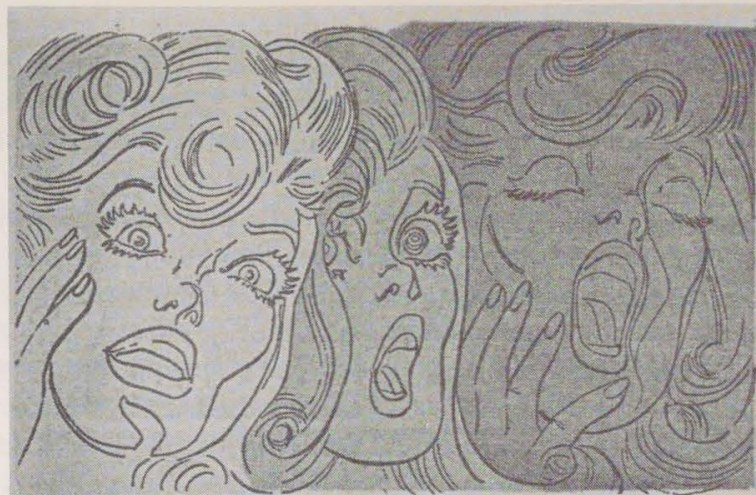

HALLUCINOGENS act on the central nervous system to produce weird sensations by distorting time, space, sight and sound. Their impact on the central nervous system is highly unpredictable.

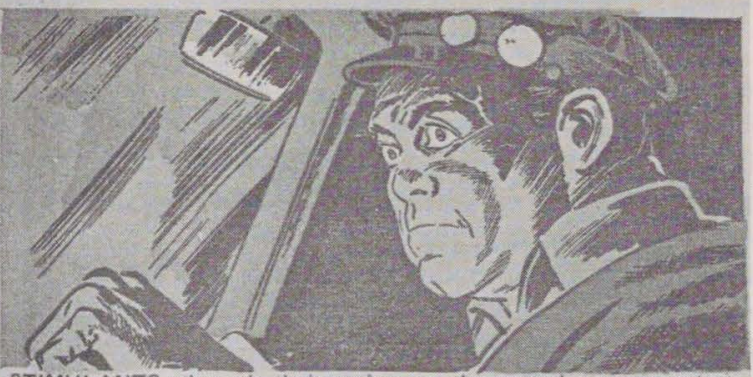

STIMULANTS, through their action on the central nervous system, cause wakefulness, increased blood pressure and decreased activity of the gastro-intestinal system. Their misuse can cause headache, dizziness, confusion, apprehension and delirium.
Although in the booklet male and female drug addicts number the same, they differ in their respective proportions of their own sex. Half of all women, but only 35 percent of the men are shown as victims of drugs, despite the fact that real-life drug addiction is much more prevalent among males. The male addicts are somber, tragic figures engaged in serious business. The women-mostly blond and scantily clad-are just hysterical. Blacks and whites are also different in ways we shall see as we examine some of the illustrations.

The cover (Figure 2) reveals the shadowy world of drug abuse. A bushy-haired young man smirks contentedly as he is about to puff on a joint. A demure blond reaches for a syringe about the size of a short bicycle pump. An equally oversized bottle of pills rests on the table between them. Through the window we can see the sunlit campus scene, supporting popular assumptions about the prevalence of drug use on campus. In fact, however, the survey of Drugs and American Youth by the University of Michigan's Institute for Social Research (1972) found less drug abuse on campus than off. The highest rate of conversion to drugs occurred after leaving high school and among the groups most likely to enter military service rather than college.

A few pages later our eyes fall on three faces of Blondie (Figure 3). She goes into wide-eyed, full-lipped hysterics, and then hallucinates with eyes closed, mouth wide open. The male user, on the other hand, is doing a man's work. He is a 
truck driver in work clothes, union buttons on his cap, using stimulants to keep awake at night on the road.

Next comes a lesson in comic-book history (Figure 4). It begins with the Western fantasy of exotic oriental religious ceremonies complete with monster-gods, inscrutable faces, and gyrating belly-dancers. Dipping even farther back into the mists of prehistory, we see a "nomadic tribe in Southern Russia" sniff poppy seed around the campfire. (For the edification of Boy Scouts?)

On the next page we come upon the drug-crazed hordes of Southeast Asia, so hopped-up on the hashish that they rush headlong into their deaths (Figure 5). The story served the British Empire and the Foreign Legion even before American troops (with their drug problems) fought and killed Southeast Asians on their own native soil. These ape-like creatures, and the two ceremonial dancing girls on the previous page, are the only nonwhite drug users portrayed in the book. A favored media "solution" to the delicate problem of overtly unfavorable portrayal is to take nonwhites back into "history" where they can be shown as naturally savage fanatics and primitives. Contrast the savagery on top of Figure 5 with the nobility in the bottom frame. Cannons and guns (in white hands) indicate that we are now in civilized times. Here drugs are used not to send ape-men into mindless slaughter but to "relieve suffering." Unfortunately, explains the caption, many of the soldiers thus treated returned to civilian life as addicts. They were considered sick men.
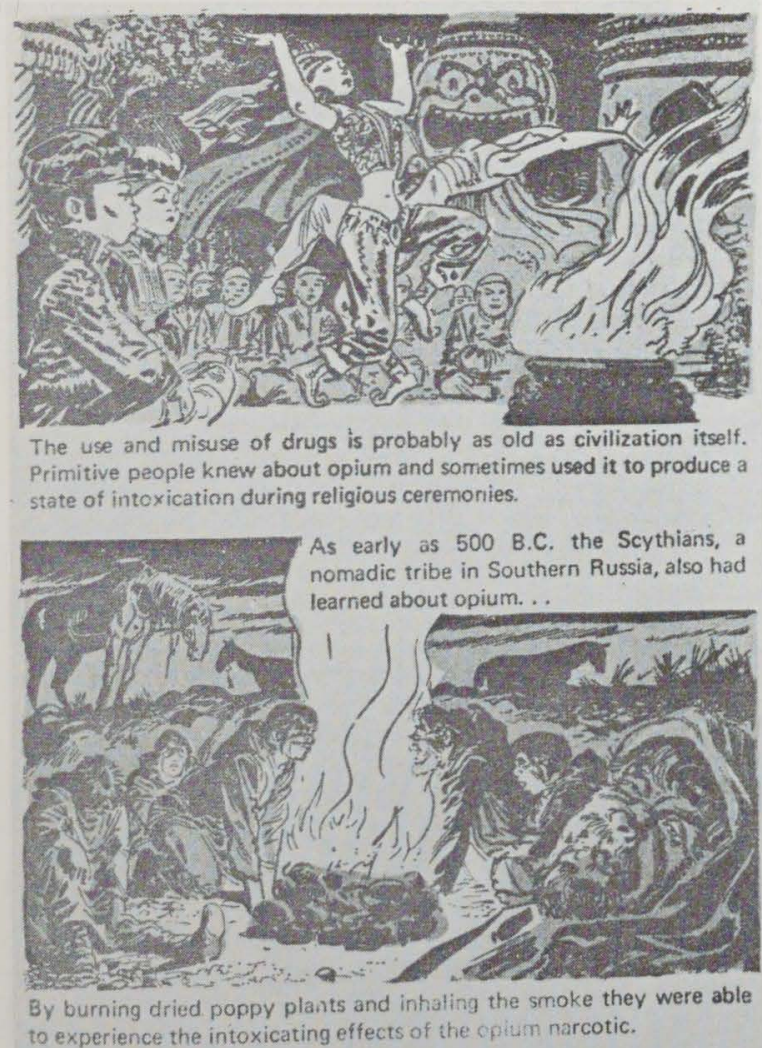

Figure 4
In Southeast Asia, young warriors were sometimes keyed up for battle to the point where they rushed headlong to their deaths due to the psychoactive effects of hashish, a concentrated preparation of mari-

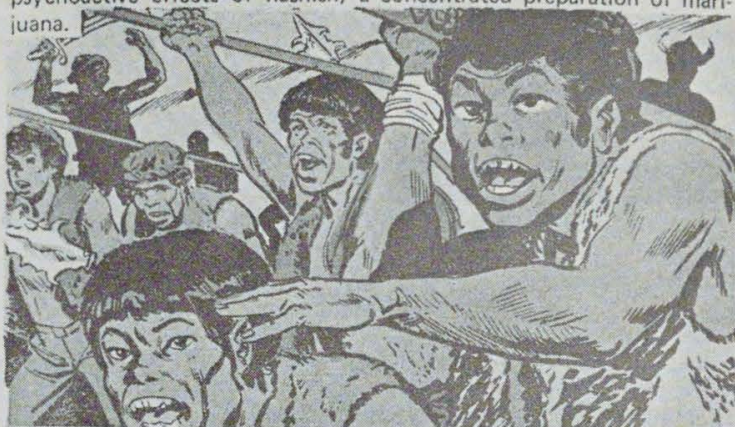

By the time of the Civil War, opium was used as a pain killer. Wounded soldiers were treated with morphine, the major constituent of opium. to relieve suffering.

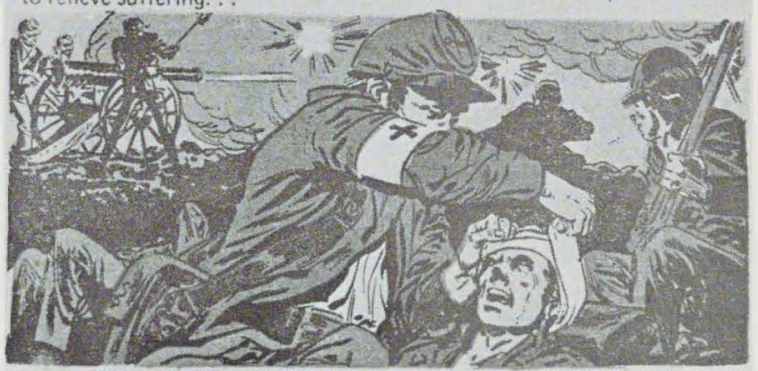

. Unfortunately, many of them returned to civilian life with an addiction not then understood, but commonly referred to as "Soldier's Disease."

Figure 5

But not for long. The next headline (Figure 6) marks the transition from sickness to crime. The picture supplies what illustrated manuals call the "how-to-do-it," showing the well-aimed shot being self-administered into the powerful fisted arm.

Soon addicts become criminals in the cultural as well as the legal sense. The cultural function of this category is to stigmatize a variety of presumably associated trangressions. The bottom frame of Figure 6 illustrates that function. A glassy-eyed bearded hippie addict wearing a peace symbol is shown panhandling a well-dressed young woman. The tendency to piggyback an overtly political message onto the drug education story recurs a few pages later.

After some frames showing pushers, an anxiety-ridden female addict, policemen grabbing a hopped-up bank robber, a white male teacher lecturing to a mixed audience, marijuana plants, and how to roll a joint, we come to a pot party. This time Blondie wears the peace symbol (Figure 7). As the caption speaks of "impairment of judgment and confusion," she passes the joint to two intellectual types as other sophisticates cavort in the background. The bottom frame gives examples of further hazards of marijuana smoking, some of them misleading.

The next page below introduces a sequence of frames in horror-comic style (Figure 8). A chief social function of horror as a cultural ritual is the scaring of women to (and 
IS DRUG ABUSE A SICKNESS OR A CRIME?

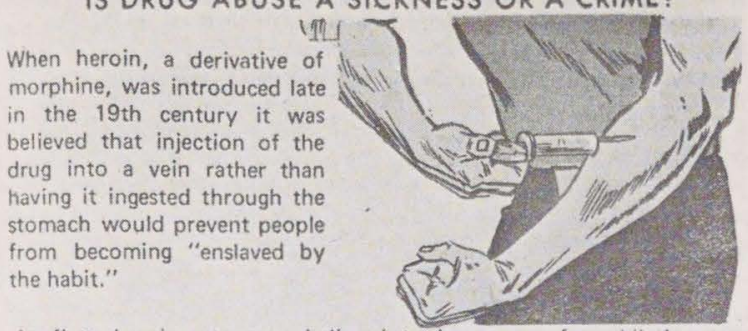

At first, heroin was even believed to be a cure for addiction to

morphine. It turned out that heroin produced an. even stronger

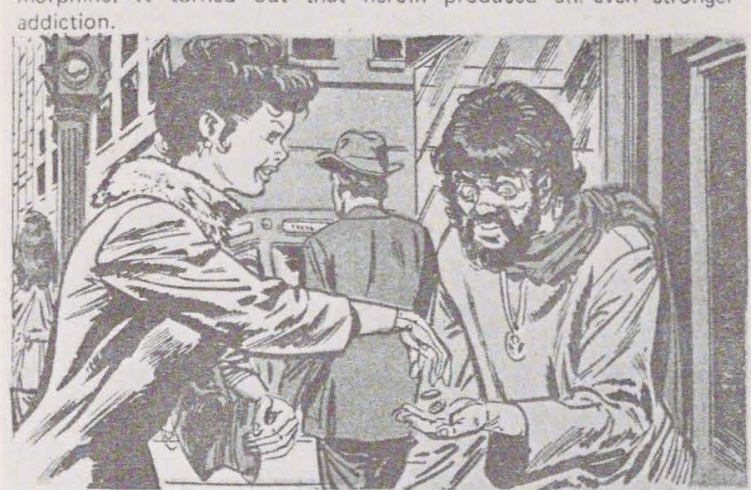

With the nature of addiction poorly understood, public opinion accused the drug rather than the user. Perhaps this attitude stemmed from the fact that so many had unwittingly become dependent upon drugs. As a result, addicts at that time were pitied more than they were condemned.

Figure 6 with) death. The ultimate sexual put-down, rape by a beast, is usually part of the fun. Here we see all faces of Blondie shrieking in psychedelic horror as monsters fall upon her. A giant bird descends with claws ready and long sharp beak and tongue poised for action. A death head puts a bony finger on her curly locks.

The sex-role message is further developed through frames (not shown here) depicting one woman raging and two others buying and using amphetamines while a male druggist looks worried and a male scientist is engaged in laboratory research.

Next we see Blondie green with terror (Figure 9). She is caught in an imaginary cobweb, with fantasy insects crawling over her curvaceous body. She is clad in a negligee and is writhing on a sofa, agonizing over how best to scratch the itch. Underneath that scene, the Male Thinker sits in a torn work shirt, silhouetted against a beam of light, contemplating suicide. To be or not to be, that is his question.

After frames of another male scientist, two male doctors, two female nurses, and "drug abusers" of both sexes (not shown), we come to Blondie again (Figure 10). She has shed her negliee and moved from the sofa into bed, alluring as ever, still itching and twitching in horror. The insects, skeleton, and long-beaked bird now become a giant snakedragon with fangs and a forked tongue, literally enveloping and ready to rape the terrified woman victim. "The torture of one horrible withdrawal," state the bottom caption "far outweighs any possible pleasure....
A marijuana cigarette burns rapidly and is often shared by several persons. It produces varying effects such as hilarity, distortion of sensations and perception, impairment of judgment and confusion.

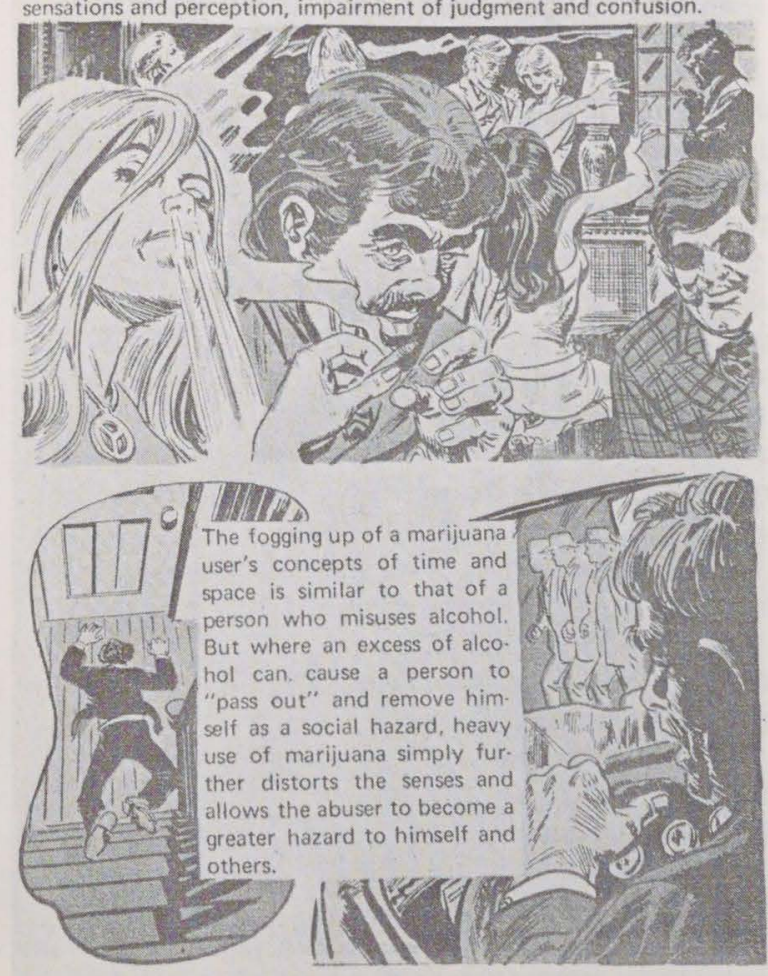

LSD, nicknamed "acid", is a chemical in the family of hallucinogens. Like other hallucinogens, LSD brings to the user an escape from realism.

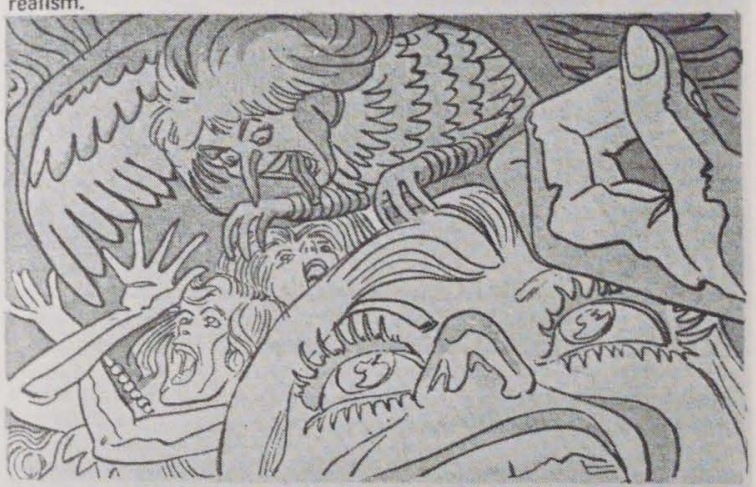

LSD users imagine all sorts of weird things-like thinking they are birds or vicious animals .... or even other people. The impact on the mind is great and sometimes of long duration.

LSD "trips" produce not only varying reactions among different users, but different results from time to time with repeat users. No one, even on a planned repeat trip, can foretell what will happen. The reaction might range anywhere from euphoria to terror.

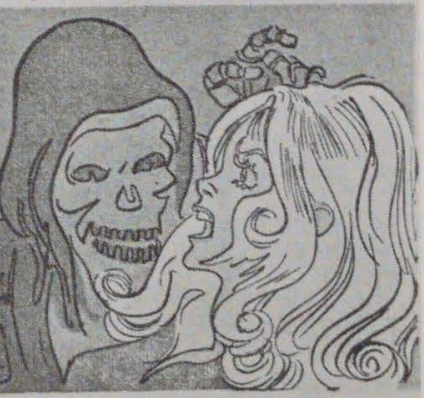

Figure 7

Figure 8 
Next are frames (not shown here) depicting a poppy field, another male physician, three firemen, three male underworld characters, and another hysterical woman. Later, as if one snake would not have been enough, we see six slimy tentacles of a hairy monster grab Blondie in the arms, legs, and thigh (Figure 11).

In the lower half of the page, the male figure is doing difficult, dangerous work. The sadistic imagery of the female victim again contrasts with the male self-image in serious (if illicit) business. While furry tentacles wrap around her body, he reaches for pearls and precious stones "to feed his ugly habit."

Soon we come to the first and only picture in which Blondie is not an alluring, if hysterical, sex symbol (Figure 12). The potent potions worked their magic too well. She is sitting on a park bench suggestively near a trash can, looking poor, sloppy, stupid, and pregnant.

Woman's fate is biology; man's is society. She is sentenced for life and more; "she knows," claims the caption, that "the baby may be born an addict." The Male Thinker pays for his mistake in jail and risks "chances for employment and promotion." Culture sets each his or her own "booby trap."

\section{THE HIDDEN MESSAGE AND HOW TO COUNTER IT}

The hidden message of "drug abuse" is that it all depends on who you are: man or woman, white or black, native American or foreigner, rich or poor, solid citizen or
Detoxification (withdrawal) from barbiturates is even more dangerous than from heroin and should be done gradually, ALWAYS under the supervision of a physician.

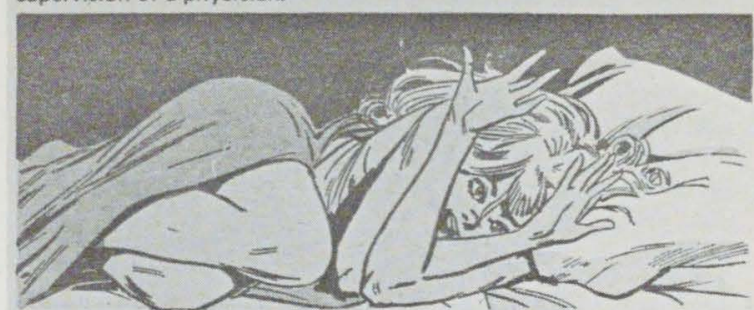

As with heroin, there is nervousness, muscle twitching, tremor and a sudden drop in blood pressure. After about 24 hours from the last dose. the abuser becomes desperate for more drugs. After 36 to 72 hours, agonizing convulsions begin.

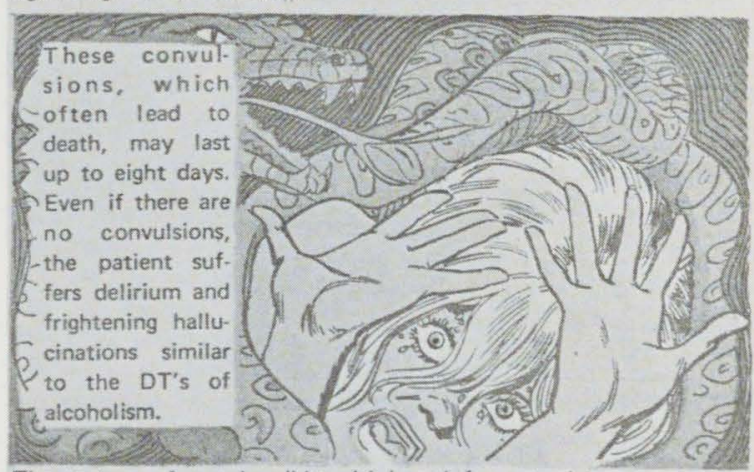

The torture of one horrible withdrawal far outweighs any possible pleasure derived from the abuse.

Figure 10

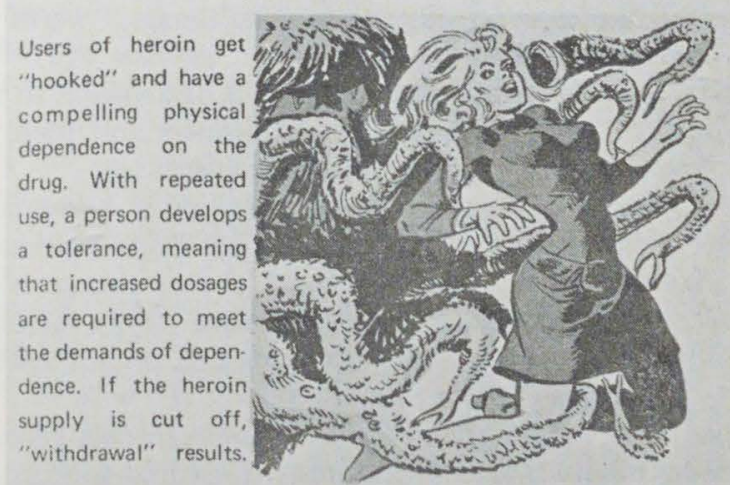

A feeling that insects are crawling over. one's body is often the Amphetamine use, when carried to the point of dependence, offers many hazards. As with barbiturates, there is an increasing demand by the body for larger doses to produce a "high." When drugs are not available, unpleasant reactions usually follow. .

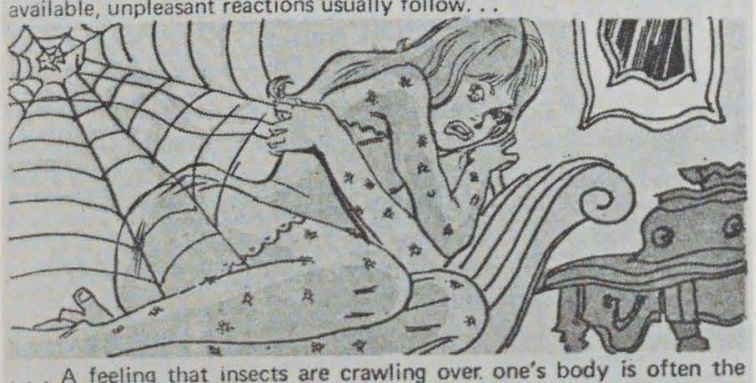
unhappy reward of users of amphetamines and other stimulants such as METHAMPHETAMINE and COCAINE.

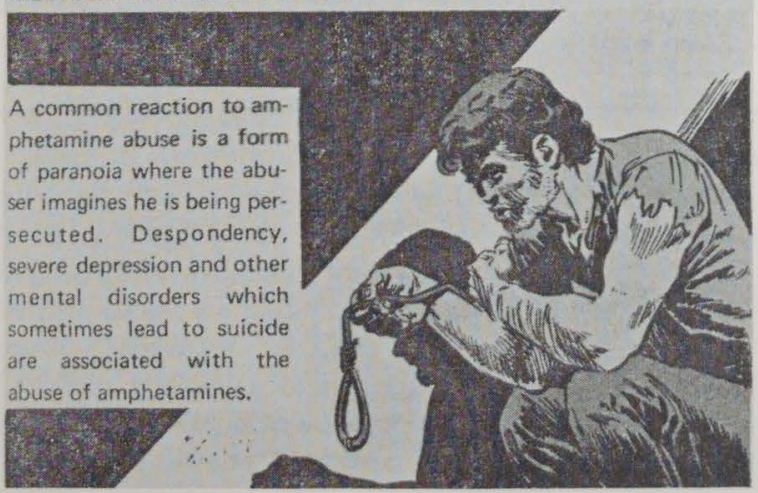

Figure 9

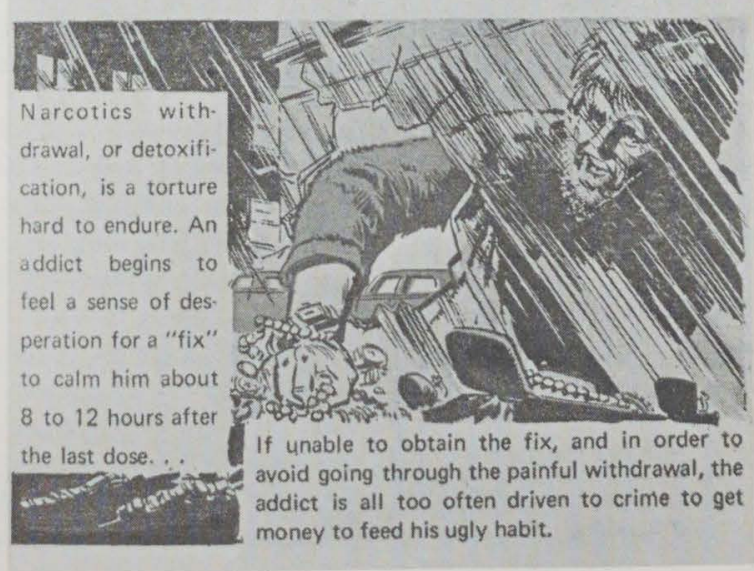

Figure 11 


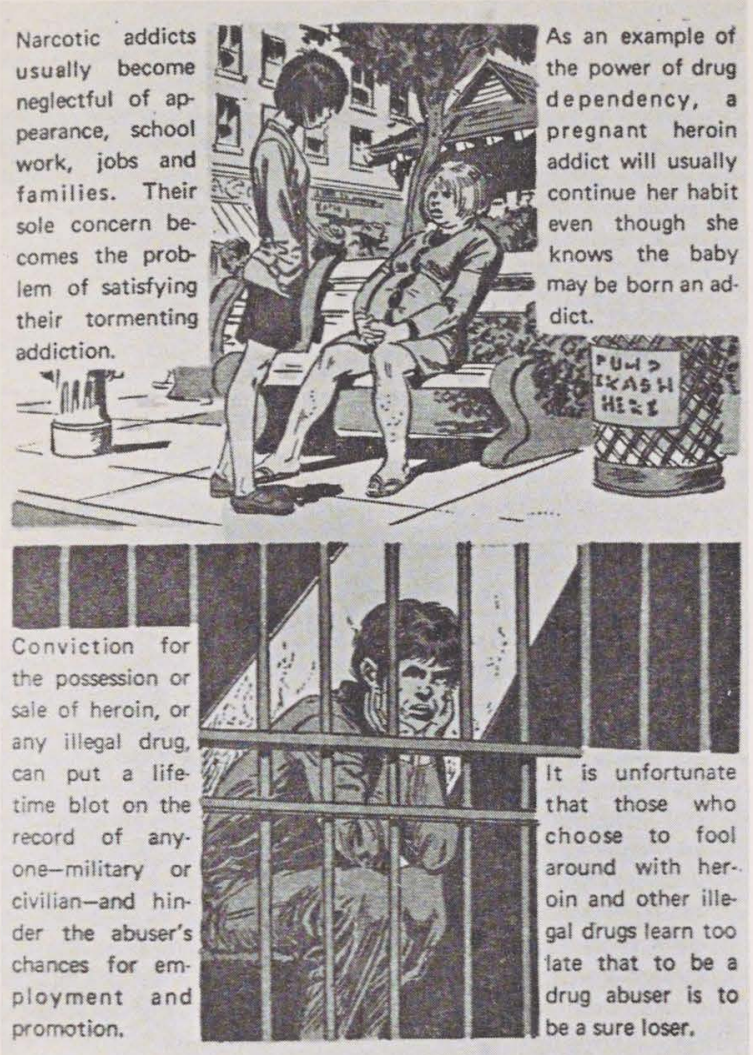

Figure 12

longhaired hippy peacenik. "It is unfortunate," warns the last caption, "that those who choose to fool around .... learn too late that to be a drug abuser is to be a sure loser." For, you see, there are winners and there are losers; follow no siren song promising easy passage.

The implicit lesson recalls the paradox of commodity culture preaching salvation through the consumption of illusions for a price. The tragic hero of that culture is the dutiful consumer chained to his purchasing habits, including the ultimate delusion of liberation through potent potions for pleasure, power, and profit.

This way of dealing with "drug abuse" can only generate increasing misery and conflict until its cultural sources and social uses are recognized and altered. That will not be easy or painless, because the sources run deep and the uses benefit powerful groups in our society. Of course, any useful therapy and all alleviation of suffering and destructive dependency are to be supported. But a counter-scenario is needed that would be of sufficient sweep and scope to begin to turn the tide.

First, all advertising, and not only patent medicine and other drug commercials, would have to be scrutinized by their producers to avoid promising spurious values and unrealistic expectations of the achievement of feelings of mastery and power. Similarly, teachers, parents, and critics should oppose the celebration of irrationality and the attribution of magic or superhuman virtues to be derived from any mechanical or chemical intervention. I am not suggesting that such (or any) subjects are not legitimate material for fiction and drama, but rather that our critical sensibilities should be attuned to these symbol systems in the same way as they are to many other themes of sensitive human relevance. And, finally, the implicit social content and covert communication of all types of imagery, especially "drug abuse" literature, must be examined for the unwitting reinforcement of the very pressures that make dangerous drugs so attractive a risk to so many.

\section{REFERENCES CITED}

Ater, Malcolm W.

1972 Personal communication.

Feiffer, Jules (Ed.)

1965 The Great Comic Book Heroes. New York: Bonanza Books. Gerbner, George

1958a The Social Role of the Confession Magazine. Social Problems 6:29-40.

1958b The Social Anatomy of the Romance-Confession Cover Girl. Journalism Quarterly 35:299-306.

1972a Communication and Social Environment. Scientific American 227:153-160.

1972b Violence in Television Drama: Trends and Symbolic Functions. In Television and Social Behavior. Vol. 1, Content and Control. G. A. Comstock and E. A. Rubinstein, eds. Washington, DC: Government Printing Office.

1973 Teacher Image in Mass Culture; Symbolic Functions of the "Hidden Curriculum." In Communications Technology and Social Policy. George Gerbner, Larry P. Gross, and William H. Melody, eds. New York: John Wiley and Sons.

Hansen, Donald A., and J. Herschel Parsons

1968 Mass Communication: A Research Bibliography. Santa Barbara, CA: Glendessary Press.

New York Times

1972 (July 25)

Philadelphia Inquirer

1972 (July 25) 